\title{
Farmers Participatory Evaluation on Performance of Red gram + Soybean Intercropping vis-a-vis Sole Cotton under Rainfed Medium Soils of Telangana
}

\author{
Md. Latheef Pasha ${ }^{1 *}$, S. Sridevi ${ }^{1}$, M. Goverdhan ${ }^{1}$, \\ P. Raghu Rami Reddy ${ }^{2}$ and Ch. Pragathi Kumari ${ }^{1}$ \\ ${ }^{1}$ AICRP on Integrated Farming Systems, Professor Jayashankar Telangana State Agricultural \\ University, Rajendranagar-500 030 Hyderabad, Telangana, India \\ ${ }^{2}$ Regional Agricultural Research Station, Warangal, Telangana, India \\ *Corresponding author
}

\begin{tabular}{|l|}
\hline K e y w o r d s \\
$\begin{array}{l}\text { Crop diversification, } \\
\text { Redgram + soybean, Sole } \\
\text { cotton, Cotton kapas } \\
\text { equivalent yield, } \\
\text { Technology gap, } \\
\text { Technology index }\end{array}$ \\
\hline Article Info \\
\hline $\begin{array}{l}\text { Accepted: } \\
\text { 10 March } 2018 \\
\text { Available Online: } \\
\text { 10 April } 2018\end{array}$ \\
\hline
\end{tabular}

\section{Introduction}

Cotton is the most important commercial and fiber crop Telangana state grown in 16.51 lakh ha with a production of 49.40 lakh bales and productivity of $515 \mathrm{~kg} \mathrm{ha}^{-1}$ (AICCIP 2014 15). Warangal is one of the major cotton 15). Warangal is one of the major cotton
Crop diversification with resource efficient and remunerative cropping systems is a sustainable agricultural practice. On farm demonstrations with diversified cropping system of Redgram + soybean Vis-a-Vis farmers' practice of sole cotton were conducted in ten farmer's locations of Warangal district of Telangana state. Crop diversification with red gram + soybean realized $29.9 \%$ higher $\left(3706 \mathrm{~kg} \mathrm{ha}^{-1}\right)$ mean cotton kapas equivalent yield over farmer's practice of cultivation of sole cotton $\left(2852 \mathrm{~kg} \mathrm{ha}^{-1}\right)$. Mean technology and extension gap were $594 \mathrm{~kg} \mathrm{ha}^{-1}$ and $854 \mathrm{~kg} \mathrm{ha}^{-1}$ respectively. Technology index ranged from 4.5 to $24.1 \%$ with an average value of $13.8 \%$. The mean gross and net returns of diversified cropping system were Rs 155658 and Rs 119140, while sole cotton recorded a mean Rs 119784 and Rs 69529 of gross and net returns ha ${ }^{-1}$ respectively. Mean BC ratio of 4.3 was earned in improved cropping system as against the 2.4 under sole cotton system. Mean additional returns in improved cropping system were Rs 35874 ha $^{-1}$ with a mean effective gain of Rs $49611 \mathrm{ha}^{-1}$. In Improved cropping systems, mean total productivity per day was $10.2 \mathrm{~kg} \mathrm{ha}^{-1}$ day $^{-1}$ with a mean profitability of Rs 326 per day as against the mean total productivity of $7.8 \mathrm{~kg} \mathrm{ha}^{-1} \mathrm{day}^{-1}$ in sole cotton system. Average Production Use Efficiency was $20.6 \mathrm{~kg} \mathrm{day}^{-1}$ in improved cropping system, while in sole cotton system it was $17.3 \mathrm{~kg} \mathrm{day}^{-1}$. Mean Relative Productive Use Efficiency and Relative Economic Efficiency were 29.9 and 71.4 respectively indicated the edge in productive economic parameters indicating the profitability of diversified cropping system. growing districts of the state, with 2.5 lakh hectares of area. The crop is grown on diverse kinds of soils varying from fine textured black soils to coarse textured red soils. However, $34^{\text {th }}$ of the area spreads in rainfed light soils under continuous sole cotton over the years and farmers have been over enthusiastic on 
cultivation of $B t$ cotton. Kapas yield of cotton is ranging from 10-12 $\mathrm{q} \mathrm{ha}^{-1}$ in the district and with changing climate, occurrence of sucking pests and diseases, micro nutrient deficiencies, alteration of soil physiography making this ecosystem highly fragile and threatening the cotton productivity. On the other hand farmers are incurring high investment on cultivation of cotton by lending money from private firms and ultimately trapping in debts due to less remunerative price and unforeseen yield losses. This situation is forcing the farmers to extreme steps of suicides owing to debts. Further, ignoring of pulses in cropping pattern and dwindling of cattle population is leading to exhaustion of organic matter in light soils making the soil ecosystem more fragile with low moisture retentivity and poor fertility.

Under such circumstances, diversifying cropping systems by increasing the spatial and temporal heterogeneity of agricultural mosaics has been proposed as a feasible alternative to overcome the negative effects of modern agriculture (Burel et al., 2013). Provision of species diversity by mixed cropping is considered as advantage over sole cropping. This diversification tends to promote yield stability because all the crops in a mixed cropping culture are not likely to be affected by weather vagaries or pests and diseases and prompts a farmer to resort to mixed cropping.

Soybean (Glycine max L.) is a dual purpose most important rainy season crop to meet pulse and oil requirements. It has a great nutritional significance, with over 38-40\% protein and $18-20 \%$ oil and has recognized as a potential supplementary source of edible oil. It is also highly adaptable to varying soil and climatic conditions, giving fairly high yields compared to other pulse crops (Padhi and Panigrahi, 2006). Soybean offers good potential to get involved in the cropping sequences or intercropping systems. It is a short duration (85 to 130 days depending on the latitude) leguminous energy rich crop. It is relatively tolerant to drought, excessive moisture, low $\mathrm{pH}$ and high aluminum content (Billore, 2014). Further its cultivation does not cause any allelopathic effect on companion/succeeding crops, extends benefits of 45 to $60 \mathrm{~kg}$ residual nitrogen per hectare to the succeeding crop and creates salutary physio-chemical environment in the soil for crop growth (Kumar et al., 2012). Apart from these, the practice of intercropping also reduces the population density of insects-pests as the intercrop may not serve as their host (Viglizzo et al., 2012). Intercropping also demonstrate weed control advantages over sole crops as intercrops are more effective than sole crops and usurp resources from weeds or suppress weed growth through allelopathy (Shennan, 2008). Soybean due to its trade and industrial significance and adaptability to varied agro-climatic conditions occupies greater part of potential cultivated area as an integral part of prevailing cropping systems in India and world over.

In Telanagana state, at present soybean is cultivated over 0.24 million hectares with an annual production of 0.25 million tones and productivity of $1036 \mathrm{~kg} \mathrm{ha}{ }^{-1}$ (Telangana Directorate of Economics and statistics 2017). However, productivity of soybean can further be increased by intercropping or with potential crop sequence. Area under soybean is increasing enormously in Northern Telanagana districts due to better yield potential and market price. Pigeon pea being a predominantly rainfed crop is one of the most important and potential component of intercropping in semi-arid areas. It is generally intercropped with sorghum, cotton and maize in northern Telangana districts. Soybean is also feasibly intercropped with pigeon pea for enhancing the potential of crop productivity. Keeping in view of the above, redgram inter cropped with soybean is evolved as an alternative sustainable and climate smart 
cropping system to sole cotton in rainfed medium vertisols.

\section{Materials and Methods}

Front line demonstrations on Redgram + soybean intercropping was conducted by On Farm Research Centre All India Coordinate Research Project on Integrated Farming Systems in 10 farmer locations of Warangal district during the year 2016-17 with an objective to study the production potential of improved cropping system of Red gram + soybean intercropping in comparison with farmers practice of sole cotton under rainfed medium soils. An area of 0.4 ha per each location was chosen for study. Test varieties were LRG-41 and JS-335 for Redgram and soybean respectively. Redgram variety, LRG41 matures in 180 days, suitable for cultivation in black cotton soils and tolerant to Helicoverpa armigera with a yield potential of 20-25 q ha ${ }^{-1}$ Soybean variety JS 335 comes to maturity in 90-95 days with yield potential of 20-25 q ha ${ }^{-1}$. Sole cotton cultivation with $B t$ hybrid (farmer's practice) was compared as control. Sowings of crops in both the treatments were done during $2^{\text {nd }}$ week to end of June month.

Intercropping of red gram and soybean $\mathrm{g}$ was done in additive row series in 1:5 ratio at a spacing of $30 \times 5 \mathrm{~cm}$ for soybean and $15 \mathrm{~cm}$ apart with in plants of red gram row. Seed rate of $2 \mathrm{~kg} \mathrm{ha}^{-1}$ and $70 \mathrm{~kg} \mathrm{ha}^{-1}$ of redgram and soybean respectively was adopted. Seed treatment with thiram @ $3 \mathrm{~g} / \mathrm{kg}$ of seed followed by $5 \mathrm{ml}$ of imidacloprid $/ \mathrm{kg}$ of seed to prevent pest and diseases. All management practices for weed, nutrient, pest and diseases were adopted as per the recommendations of PJTSAU. A rainfall of $990 \mathrm{~mm}$ was received in 65 rainy days and the crop was maintained rainfed without any irrigations. The data on grain yield was collected by random crop cutting method. Cotton seed Equivalent yield was calculated by converting the seed yield of soybean and redgarm into cotton equivalent Yield on the basis of sale prices of respective crops.

(Redgram yield $\left(\mathrm{kg} \mathrm{ha}^{-1}\right) \mathrm{x}$ price of red gram $\left(\mathrm{Rs} \mathrm{kg}^{-1}\right)+$ Soybean yield $\left(\mathrm{kg} \mathrm{ha}^{-1}\right) \mathrm{x}$ price of soybean $\left(\mathrm{Rs} \mathrm{kg}^{-1}\right)$

Cotton Equivalent Yield =

Cotton kapas price $(\mathrm{Rs} / \mathrm{kg})$

The check crop, cotton was cultivated with a Bt hybrid RCH 22, which has an yield potential of 25-30 q ha ${ }^{-1}$ and sown at spacing of $90 \times 45 \mathrm{~cm}$ with a seed rate of $2.25 \mathrm{~kg} \mathrm{ha}^{-1}$. All the agronomic management practices were done in accordance with recommendations of PJTSAU and kapas yield was recorded by taking three pickings up to 160 days.

Benefit Cost ratio, gross and net returns were calculated based on grain yield and prevailing market price. Per day net returns were worked out by dividing total net returns with the duration of the crop.

The extension gap, technology gap and technology index were calculated as per the following formula drawn by Samui et al., (2000).

Extension gap $=$ Yield of Improved practiceYield of farmers practice.

Technology gap $=$ Potential yield - yield of improved practice

Technology index = $\frac{\text { Technology gap }}{\text { Potential yield }}$ X 100

Production and Economic indices are calculated based on following formulae.

Additional Returns=Extension gap X Sale price 
Effective gain = Additional returns Additional cost

Returns per rupee investment $\left(\operatorname{Rs} \mathrm{Re}^{-1}\right)=\mathrm{Net}$ Returns/Cost of Cultivation

Total Productivity $\left(\mathrm{kg} \mathrm{ha}{ }^{-1}\right.$ day $\left.^{-1}\right)=$ Total productivity/365

Profitability (Rs ha ${ }^{-1}$ day $\left.^{-1}\right)=$ Total profitability/365

Production Use Efficiency is Efficiency measured in terms of yield/day

Production Use

Total grain yield of a system

Efficiency $\left(\mathrm{kg} \mathrm{ha}^{-1}\right.$ day $\left.^{-1}\right)=$

Period in days consumed to produce the yield

Total Productivity in diversified cropping system -

Total productivity in existing cropping system Relative Productive

Use Efficiency $(\%)=$ X 100

Total productivity in existing cropping system

Net Returns of diversified cropping system Net Returns of existing cropping system Relative Economic Efficiency $(\%)=$ X 100

Net Returns of existing cropping system

\section{Results and Discussion}

\section{Grain yield}

Grain yield of soybean and pigeon pea was influenced by interaction of planting pattern and intercropping system. Initial slow growth of pigeon pea provided more space for soybean development and resulted in good yield of both the component crops. The Cotton Equivalent Yield of diversified cropping system of Redgram + soybean was ranging from $3264 \mathrm{~kg} \mathrm{ha}^{-1}$ to $4107 \mathrm{~kg} \mathrm{ha}^{-1}$ across the locations and was $16.3 \%-37.3 \%$ higher than sole cotton crop yields $\left(2650 \mathrm{~kg} \mathrm{ha}^{-1}\right.$ to 3070 $\mathrm{kg} \mathrm{ha}^{-1}$ ). Mean Cotton Equivalent Yield (Table 1) of improved cropping system of Redgram + soybean was $29.9 \%$ higher (3706 kg ha ${ }^{-1}$ ) than over farmers practice of sole cotton yield $\left(2852 \mathrm{~kg} \mathrm{ha}^{-1}\right)$. Studies conducted at Adilabad, Telanagana state also indicated that Pigeon pea at $180 \mathrm{~cm}$ row spacing intercropped with six rows of soybean gave significantly higher pigeon pea equivalent yields than sole pigeon pea MRG-66 (Sreerekha and Dhurua 2009). Kasbe et al., (2010) also reported maximum yield in interaction of planting pattern 4:2 and intercropping system soybean (JS-335) + pigeon pea (BSMR-736).

\section{Economics}

Diversified cropping system of pigeon pea +soybean earned gross returns ranging from Rs 137100 to Rs 172500 across the locations. While gross returns of sole cotton under farmers practice ranged from Rs 111300 to Rs 128940 (Table 2). The mean gross returns under improved cropping systems were Rs 155658 via-a-vis Rs 119784 in sole cotton. Net returns in improved cropping systems ranged from Rs 100450 to Rs 134200 with mean value of Rs 119140, while net returns of sole cotton varied from Rs 58800 to Rs 79690 with an average net return of Rs 69529. The returns on earned per rupee investment were ranging from Rs 3.7 to Rs 4.5 with mean $\mathrm{BC}$ ratio of Rs 4.3 in improved cropping system, where as in sole cotton system the benefit was Rs 2.1-2.6 per rupee cost with mean value of 2.4. Dubey et al., (1991) reported 32 per cent more net returns due to planting of pigeon pea and soybean compared to sole pigeon pea. Halvankar et al., (2000) also observed similar results.

Per day returns ranged from Rs 558 to 746 in improved cropping system with as an average of Rs 662. 
Table.1 Grain yield, technology gap, extension gap and technology index were influenced under improved cropping system over farmers practice

\begin{tabular}{|c|c|c|c|c|c|c|c|c|c|}
\hline \multirow[t]{2}{*}{$\begin{array}{l}\text { Trial } \\
\text { No }\end{array}$} & \multicolumn{2}{|c|}{$\begin{array}{c}\text { Grain yield } \\
\left(\mathrm{kg} \mathrm{ha}^{-1}\right) \text { in Improved } \\
\text { cropping systems }\end{array}$} & \multirow{2}{*}{$\begin{array}{c}\text { Cotton } \\
\text { Equivalent } \\
\text { Yield (Kg } \\
\text { ha }^{-1} \text { in } \\
\text { Improved } \\
\text { system }\end{array}$} & \multirow{2}{*}{$\begin{array}{c}\text { Potential } \\
\text { yield } \\
\left(\mathrm{kg} \mathrm{ha}^{-1}\right) \\
\text { of } \\
\text { Improved } \\
\text { system }\end{array}$} & \multirow{2}{*}{$\begin{array}{c}\text { Sole cotton } \\
\text { yield } \\
\left(\mathrm{kg} \mathrm{ha}^{-1}\right) \text { in } \\
\text { Farmers } \\
\text { practice }\end{array}$} & \multirow{2}{*}{$\begin{array}{c}\% \text { increase } \\
\text { in yield over } \\
\text { farmers } \\
\text { practice }\end{array}$} & \multirow[t]{2}{*}{$\begin{array}{c}\text { Technology } \\
\text { gap } \\
\left(\mathrm{kg} \mathrm{ha}^{-1}\right)\end{array}$} & \multirow[t]{2}{*}{$\begin{array}{l}\text { Extension } \\
\text { gap } \\
\left(\mathrm{kg} \mathrm{ha}^{-1}\right)\end{array}$} & \multirow[t]{2}{*}{$\begin{array}{c}\text { Technology } \\
\text { Index }\end{array}$} \\
\hline & Soybean & Red gram & & & & & & & \\
\hline 1 & 1885 & 1650 & 3283 & 4300 & 2650 & 23.9 & 1017 & 633 & 23.7 \\
\hline 2 & 1700 & 1720 & 3264 & 4300 & 2720 & 20.0 & 1036 & 544 & 24.1 \\
\hline 3 & 2280 & 2100 & 4107 & 4300 & 3040 & 35.1 & 193 & 1067 & 4.5 \\
\hline 4 & 1850 & 2060 & 3799 & 4300 & 2680 & 41.7 & 501 & 1119 & 11.7 \\
\hline 5 & 2250 & 1965 & 3913 & 4300 & 2850 & 37.3 & 388 & 1063 & 9.0 \\
\hline 6 & 2190 & 1805 & 3667 & 4300 & 2740 & 33.8 & 633 & 927 & 14.7 \\
\hline 7 & 2010 & 1795 & 3547 & 4300 & 3050 & 16.3 & 753 & 497 & 17.5 \\
\hline 8 & 2330 & 1835 & 3790 & 4300 & 2970 & 27.6 & 510 & 820 & 11.9 \\
\hline 9 & 2380 & 1940 & 3957 & 4300 & 3070 & 28.9 & 343 & 887 & 8.0 \\
\hline 10 & 2160 & 1870 & 3735 & 4300 & 2750 & 35.8 & 565 & 985 & 13.2 \\
\hline Mean & 2103.5 & 1874 & 3706 & 4300 & 2852 & 29.9 & 594 & 854 & 13.8 \\
\hline
\end{tabular}

Table.2 Economics as influenced under improved cropping system over farmers practice

\begin{tabular}{|c|c|c|c|c|c|c|c|c|c|c|}
\hline \multirow{2}{*}{$\begin{array}{l}\text { Trial } \\
\text { No }\end{array}$} & \multicolumn{2}{|c|}{ Cost of Cultivation (Rs ha' ${ }^{-1}$ ) } & \multicolumn{2}{|c|}{ Gross Returns (Rs ha') } & \multicolumn{2}{|c|}{ Net Returns (Rs ha $\left.{ }^{-1}\right)$} & \multicolumn{2}{|c|}{ B: C ratio } & \multicolumn{2}{|c|}{ Per day Net Returns (Rs ha $\left.{ }^{-1}\right)$} \\
\hline & $\begin{array}{c}\text { Improved } \\
\text { system }\end{array}$ & $\begin{array}{l}\text { Farmers } \\
\text { Practice }\end{array}$ & $\begin{array}{c}\text { Improved } \\
\text { system }\end{array}$ & $\begin{array}{l}\text { Farmers } \\
\text { Practice }\end{array}$ & $\begin{array}{c}\text { Improved } \\
\text { system }\end{array}$ & $\begin{array}{l}\text { Farmers } \\
\text { Practice }\end{array}$ & $\begin{array}{c}\text { Improved } \\
\text { system }\end{array}$ & $\begin{array}{l}\text { Farmers } \\
\text { Practice }\end{array}$ & $\begin{array}{c}\text { Improved } \\
\text { system }\end{array}$ & $\begin{array}{l}\text { Farmers } \\
\text { Practice }\end{array}$ \\
\hline 1 & 36250 & 52500 & 137875 & 111300 & 101625 & 58800 & 3.8 & 2.1 & 565 & 356 \\
\hline 2 & 36650 & 50500 & 137100 & 114240 & 100450 & 63740 & 3.7 & 2.3 & 558 & 386 \\
\hline 3 & 38300 & 49800 & 172500 & 127680 & 134200 & 77880 & 4.5 & 2.6 & 746 & 472 \\
\hline 4 & 35700 & 46800 & 159550 & 112560 & 123850 & 65760 & 4.5 & 2.4 & 688 & 399 \\
\hline 5 & 36400 & 49300 & 164325 & 119700 & 127925 & 70400 & 4.5 & 2.4 & 711 & 427 \\
\hline 6 & 34720 & 46200 & 154025 & 115080 & 119305 & 68880 & 4.4 & 2.5 & 663 & 417 \\
\hline 7 & 36300 & 54550 & 148975 & 128100 & 112675 & 73550 & 4.1 & 2.3 & 626 & 446 \\
\hline 8 & 38450 & 53400 & 159175 & 124740 & 120725 & 71340 & 4.1 & 2.3 & 671 & 432 \\
\hline 9 & 37400 & 49250 & 166200 & 128940 & 128800 & 79690 & 4.4 & 2.6 & 716 & 483 \\
\hline 10 & 35000 & 50250 & 156850 & 115500 & 121850 & 65250 & 4.5 & 2.3 & 677 & 395 \\
\hline Mean & 36517 & 50255 & 155657.5 & 119784 & 119141 & 69529 & 4.3 & 2.4 & 662 & 421 \\
\hline
\end{tabular}


Table.3 Production and Economic indices as influenced under improved cropping system over farmers practice

\begin{tabular}{|c|c|c|c|c|c|c|c|c|c|}
\hline $\begin{array}{l}\text { Trial } \\
\text { No }\end{array}$ & $\begin{array}{l}\text { Additional } \\
\text { Returns }\end{array}$ & $\begin{array}{c}\text { Effective } \\
\text { gain }\end{array}$ & $\begin{array}{l}\text { Total pro } \\
\text { (kg ha }^{-1}\end{array}$ & $\begin{array}{l}\text { ductivity } \\
\left.\operatorname{day}^{-1}\right)\end{array}$ & $\begin{array}{l}\text { Profitability } \\
\left(\text { Rs ha }^{-1} \text { day }^{-1}\right)\end{array}$ & $\begin{array}{r}\text { Production } \\
\text { (kg h }\end{array}$ & $\begin{array}{l}\text { se Efficiency } \\
\left.\operatorname{day}^{-1}\right)\end{array}$ & $\begin{array}{c}\text { Relative } \\
\text { Productive Use }\end{array}$ & $\begin{array}{l}\text { Relative } \\
\text { Economic }\end{array}$ \\
\hline & $\left(\operatorname{Rs~ha}^{-1}\right)$ & $\left(\operatorname{Rs~ha}^{-1}\right)$ & $\begin{array}{c}\text { Improved } \\
\text { system }\end{array}$ & $\begin{array}{l}\text { Farmers } \\
\text { Practice }\end{array}$ & & $\begin{array}{c}\text { Improved } \\
\text { system }\end{array}$ & $\begin{array}{l}\text { Farmers } \\
\text { Practice }\end{array}$ & Efficiency (\%) & $\begin{array}{c}\text { Efficiency } \\
(\%)\end{array}$ \\
\hline 1 & 26575 & 42825 & 9.0 & 7.3 & 278 & 18.2 & 16.1 & 23.9 & 72.8 \\
\hline 2 & 22860 & 36710 & 8.9 & 7.5 & 275 & 18.1 & 16.5 & 20.0 & 57.6 \\
\hline 3 & 44820 & 56320 & 11.3 & 8.3 & 368 & 22.8 & 18.4 & 35.1 & 72.3 \\
\hline 4 & 46990 & 58090 & 10.4 & 7.3 & 339 & 21.1 & 16.2 & 41.7 & 88.3 \\
\hline 5 & 44625 & 57525 & 10.7 & 7.8 & 350 & 21.7 & 17.3 & 37.3 & 81.7 \\
\hline 6 & 38945 & 50425 & 10.0 & 7.5 & 327 & 20.4 & 16.6 & 33.8 & 73.2 \\
\hline 7 & 20875 & 39125 & 9.7 & 8.4 & 309 & 19.7 & 18.5 & 16.3 & 53.2 \\
\hline 8 & 34435 & 49385 & 10.4 & 8.1 & 331 & 21.1 & 18.0 & 27.6 & 69.2 \\
\hline 9 & 37260 & 49110 & 10.8 & 8.4 & 353 & 22.0 & 18.6 & 28.9 & 61.6 \\
\hline 10 & 41350 & 56600 & 10.2 & 7.5 & 334 & 20.7 & 16.7 & 35.8 & 86.7 \\
\hline Mean & 35873.5 & 49611.5 & 10.2 & 7.8 & 326 & 20.6 & 17.3 & 29.9 & 71.4 \\
\hline
\end{tabular}


While sole cotton system resulted in Rs 356 to 472 per day returns with mean of Rs 421 . Higher economics in improved cropping systems over sole cotton system can be attributed to higher cotton equivalent yield, high gross and net returns and lower cost of cultivation. The findings of Billore et al., (2002) also confirm that planting of pigeon pea $150 \mathrm{~cm}$ with five rows of soybean recorded maximum net returns of Rs.17, 226 $\mathrm{ha}^{-1}$ ) and Rs.22, $035 \mathrm{ha}^{-1}$ respectively.

Technology gap, extension gap and technology index

Mean Technology gap was $594 \mathrm{~kg} \mathrm{ha}^{-1}$ and it ranged from $193 \mathrm{~kg} \mathrm{ha}^{-1}$ to $1036 \mathrm{~kg} \mathrm{ha}^{-1}$. Whereas extension gap varied from 497 to $1067 \mathrm{~kg} \mathrm{ha}^{-1}$ with average value of $854 \mathrm{~kg} \mathrm{ha}^{-1}$ (Table 1). Technology index ranged from 4.5 to $24.1 \%$ with an average value of $13.8 \%$.

Technology Index represents the feasible adaptability improved cropping systems from lab to land. Lower the technology index means more viability of innovative cropping system at farmer's field. Thus attaining higher yields almost close to potential yields will hasten up the adoption of improved cropping system interventions to increase the yield performance.

\section{Production and economy indices}

Additional returns in diversified cropping system ranged from Rs 20875 to 46990 $\mathrm{ha}^{-1}$ with mean additional returns of Rs 35874 ha $^{-1}$ (Table 3). Effective gain ranged from Rs $36710 \mathrm{ha}^{-1}$ to $58090 \mathrm{ha}^{-1}$ with an average effective gain of Rs $49611 \mathrm{ha}^{-1}$ in improved cropping system. Total productivity per day in improved cropping systems varied from 8.9 $\mathrm{kg}$ to $11.3 \mathrm{~kg} \mathrm{ha}^{-1} \mathrm{day}^{-1}$ with mean value of $10.2 \mathrm{~kg} \mathrm{ha}^{-1}$ day $^{-1}$ as against $7.8 \mathrm{~kg} \mathrm{ha}^{-1}$ day $^{-1}$ in sole cotton system which ranged from 7.3 to $8.4 \mathrm{~kg} \mathrm{ha}^{-1}$ day $^{-1}$. Mean Profitability of diversified cropping system per day was Rs 326 and it ranged from Rs 275 to 368 .

Production Use Efficiency of diversified redgram + soybean system ranged from 18.1 $\mathrm{kg}$ to $22.8 \mathrm{~kg} \mathrm{day}^{-1}$ with an average of $20.6 \mathrm{~kg}$ day $^{-1}$, while it was 16.1 to $18.6 \mathrm{~kg} \mathrm{day}^{-1}$ with mean of 17.3 in sole cotton system. Relative Productive Use Efficiency of redgram + soybean system fluctuated from 16.3 to $41.7 \%$ with an average of $29.9 \%$ whereas Mean Relative Economic Efficiency was $71.4 \%$ and it ranged from 53.2 to $88.3 \%$.

Results obtained from computation of indices, yield and returns showed a significant advantage of intercropping redgram +soybean in exploiting the resources of the environment compared to sole cropping of cotton in rainfed regions of Telangana state.

\section{References}

AICCIP 2014-15. Annual Report of Cotton, Coimbatore p.1-12.

Billore, S.D., 2014. Assessment of Soybean Based Cropping System Productivity Trends and Sustainability under Various Tillage Systems. Soybean Res., (Special issue), 45-60.

Billore, S.D., Joshi, O.P., and Ramesh, A., 2002. International Agronomy Congress on Balancing food and Environmental Security- A continuing challenge. pp.850.

Burel, F., Lavigne, C., Marshall, E.J.P., Moonen, A.C., Ouin, A., and Poggio, S.L., 2013. Landscape ecology and biodiversity in agricultural landscapes. Agric. Ecosys. and Environ. 166: 1-2.

Dubey, O. P., Garg, D. C., Dixit, J. P. and Tiwari, K. P. (1991). Intercropping in short duration pigeonpea. Indian $\mathrm{J}$. Agron., 36: 253-254.

Halvankar GB, Philips Varghese, Taware SP and Raut VM. 2000. Evaluation of 
intercropping patterns of soybean in pigeonpea. Indian J. Agron., 45: 530533.

Kasbe, A.B., Karanjikar, P.N., Dhoke, M.K., and Deshmukh, R.B., 2010. Effect of planting pattern on soybean and pigeonpea intercropping system. International Journal of Agricultural Sciences, 6(1): 330-332.

Kumar P, Rana K S and Rana D S (2012) Effect of planting systems and phosphorus with biofertilizers on the performance of sole and intercropping pigeon pea (Cajanus cajan) under rainfed conditions. Indian J Agron 57: 127-132.

Padhi, A. K. and Panigrahi, R. K. 2006. Effect of intercrop and crop geometry on productivity, economics, energetics and soil- fertility status of maize based intercropping systems. Indian J. Agron. 51(3): 174-177.
Samui, S.K., Maitra, S., Roy, D.K., Mandal, A.K., Saha, D., 2000. Evaluation of front line demonstration on groundnut. J. Indian Soc. Coastal Agric.Res. 18(2):180-183.

Shennan, C. 2008 Biotic interactions, ecological knowledge and agriculture. Phil. Trans. R. Soc. B 363, 717-739.

Sree Rekha, M., and Dhurua, S, 2009. Productivity of pigeon pea + soybean intercropping system as influenced by planting patterns and duration of pigeon pea varieties under rainfed conditions. Legume Res. 32(1): 51-54.

Telangana Directorate of Economics and Statistics, 2017. Statistical Year Book. Pp. 103-134.

Viglizzo, E.F., Paruelo, J.M., Laterra, P., and Jobbágyg, E.G., 2012. Ecosystem service evaluation to support land-use policy. Agric. Ecosys. and Environ., 154: 78-84.

\section{How to cite this article:}

Md. Latheef Pasha, S. Sridevi, M. Goverdhan, P. Raghu Rami Reddy and Pragathi Kumari, Ch. 2018. Farmers Participatory Evaluation on Performance of Red gram + Soybean Intercropping vis-a-vis Sole Cotton under Rainfed Medium Soils of Telangana. Int.J.Curr.Microbiol.App.Sci. 7(04): 1002-1009. doi: https://doi.org/10.20546/ijcmas.2018.704.109 